\title{
Adaptation and Resistance of Smart Valleys Bunds in Sudanians' Lowland: Experience in Four Lowlands in Burkina Faso
}

\author{
Bama Nati Aïssata Delphine ${ }^{1, *}$, Niang Dial ${ }^{2}$, Gbané Mahamaa ${ }^{2}$, Ouedraogo Ibrahima ${ }^{1}$, \\ Boube Bassirou ${ }^{2}$, Ngnepi Toukep Elvire Vanessa ${ }^{2}$ \\ ${ }^{1}$ Institut de l'Environnement et de Recherches Agricoles, Département de Production Végétale, \\ INERA, 04 BP 8645 Ouagadougou 04, Burkina Faso \\ ${ }^{2}$ Institut International d'Ingénierie de l'Eau et de l'Environnement, Laboratoire Eaux Hydro-Systèmes et Agriculture, \\ 2IE, 01BP 594 Ouagadougou 01, Burkina Faso \\ *Corresponding author: nati_aissata@yahoo.fr
}

Received April 12, 2019; Revised May 25, 2019; Accepted June 04, 2019

\begin{abstract}
Smart-Valley is an inexpensive, sustainable and participatory lowland development approach, developed by Africa-Rice in order to increase the resilience of small-scale rice producers to rainfall variability effects. The approach is based on these farmers' knowledge of their lowlands. Smart-Valley has already proven itself in West Africa's coastal countries. In these coastal areas, smart valley bunds are designed with only lowland land. But in sudanian climatic zone, the runoff is sometimes violent. Will bunds with lowland lands be resistant? Hence, this study aimed to test and adapt smart valley bunds designed for West Africa coastal areas to sudanian ecology. Twenty ha in four lowlands, five ha by site, were developed during the months of May-June 2018 follows smart valley approach. However, rubble stones were used to reinforce the main bunds and drainage channels were made if needed. The study showed that on half of the sites, the small holders farmed their lowland without carrying out any water management bunds. Smart valley adapted technology is not suitable for all the sudanian lowlands because this approach was success $75 \%$ in lowlands tested. But, in these area where smart valleys is adapted, bunds done by rubble stone slow down runoff, increases infiltration and retains a standing water that reduces the effects of pockets of drought during crop production.
\end{abstract}

Keywords: smart-valley, bund, small holder farmers, runoff, lowland

Cite This Article: Bama Nati Aïssata Delphine, Niang Dial, Gbané Mahama, Ouedraogo Ibrahima, Boube Bassirou, and Ngnepi Toukep Elvire Vanessa, "Adaptation and Resistance of Smart Valleys Bunds in Sudanians' Lowland: Experience in Four Lowlands in Burkina Faso." American Journal of Water Resources, vol. 7, no. 2 (2019): 58-61. doi: 10.12691/ajwr-7-2-3.

\section{Introduction}

Agriculture in the sudanian area is subject to water scarcity due to climate change $[1,2,3]$, thus increasing the vulnerability of small holder farmers [4,5]. Crops are facing to the pockets of drought [6] that occur during the period of growth and sometime the lack of rain at maturity [7]. It follows a drastic decline of yields $[8,9,10]$. To deal with this climate change, several actions have been undertaken to increase the resilience of small holder farmers in lowland crop production. Indeed lowlands can contribute significantly to food security due to their hydrological condition $[11,12]$. Thus, during the COP21 in Marrakech, Smart-Valleys approach [12], have been retain as a technology that will be popularized in Sub-Saharan Africa to increase adaptability of small holder farmers in this climate change condition [13] (unpublished data)). Based on a participatory, sustainable and low-cost approach, the Smart-valleys approach was developed by Africa-Rice and its research partners in
Benin and Togo. In these coastal areas, smart valley bunds are designed with only lowland land. But in sudanian climatic zone, the floods are sometimes violent. Will bunds with lowland lands be resistant? Hence, this study aimed to test and adapt smart valley bunds designed for West Africa coastal areas to sudanian ecology.

\section{Material and Method}

\subsection{Study Area}

These tests and adaptability of smart valley bunds to soudanian climatic zone have been done in four lowlands in Burkina Faso. These sites are located between $600 \mathrm{~mm}$ and $1200 \mathrm{~mm}$ isohyets from north to south (Figure 1). Climate is characterized by the alternation of a dry season from December to April with cool and dry winds, and a rainy season that lasts from May to November with warm, wet ocean winds rising. The total surface of these lowlands are 75.9 ha in Sindou, 40.6 ha in BanflagouèFon, 28 ha in Barjongo and 64 ha in Tanseiga. 


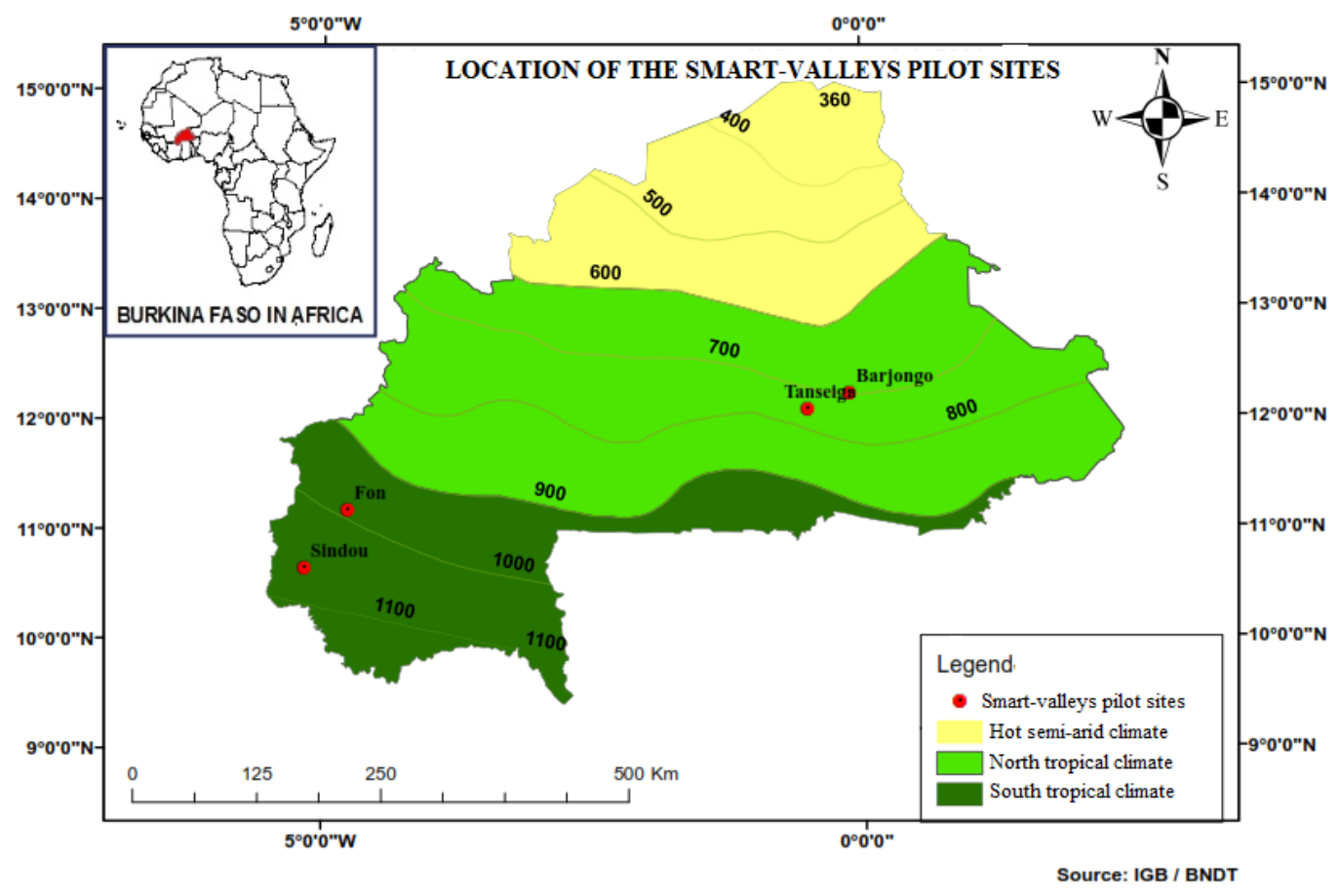

Figure 1. Location of lowlands were smart valleys have been tested

\subsection{Rainfall and Hydrological Data Processing}

The rain data used in this study have been provided by the weather station near to lowland. These are the weather station of SOSSUCO in Bérégadougou (1986 to 2016), INERA Farako-Ba (1986 to 2016), Zorgho (1980 to 2016) and Koupela (1980 to 2017). The annual average rainfall was determined and accepted representative when the coefficient of variation is less than $15 \%$. The decennial daily rainfall P10 (mm) was determined using Gumbel's law. The average decennial daily rainfall over the catchment area $\operatorname{Pm} 10(\mathrm{~mm})$ is given by the product $\alpha \times \mathrm{P} 10$ where $\alpha$ represents the catchment coefficient of the watershed (Vuillaume). This allowed to determine the decadal runoff rates Q10. Two methods were used: ORSTOM and CIEH $[15,16]$.

\subsection{Smart Valley Approach Adapted to Sudanian Areas}

On each of the four lowlands, five ha were developed during the months of May-June 2018 following the smart valley approach [17]. However, the bunds were not made only with lowland land as recommended by the method. Rubble stones were used to reinforce these bunds and drainage channels for excess water were made according to the typology of the lowlands. The damage on each bund was observed at the end of each runoff during the rainy season 2018 .

\section{Result and Discussion}

\subsection{Farmers' Knowledge of Bunds Construction in Experimental Sites}

At Tanseiga and Banflgouè-Fon, small holders farmed rice in their lowland without carrying out any water management bunds (Figure 2) which increases their vulnerability to irregular rainfall effect $[8,18]$. At Sindou, the producers understood the role that bunds play in maintaining standing water in lowland [19]. Indeed, they built bunds with only lowland land to farmed crops. And, at Barjongo, a project had developed their lowland during the previous years. However, since the development was not done in a participatory manner, as recommended by the smart valley approach, small holder farmers didn't take care of the bunds [20] at the end of the project.

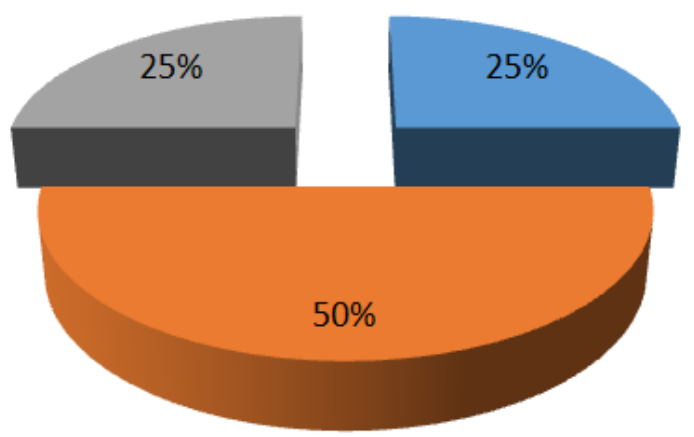

Bunds construct by farmers themselves

No experience in bunds construction

Helped in bunds construction by another project

Figure 2. Knowledge of smallholder farmers in bunds construction in smart valley sites

\subsection{Resistance of Smart Valley Adapted Bunds to Flows}

These bunds have been adapted to cope with a runoff generated by a daily rain of $100 \mathrm{~mm}$ in southern sudanian zone and $87 \mathrm{~mm}$ in northern part (Figure 3 and Figure 4) and (Table 1). In this area, sometime runoffs are violent [21]. At the Sindou, a breakage have been noted in one 
drainage channels caused by a runoff of $74 \mathrm{~mm}$ of rain, the maximum recorded during 2018 (Figure 3). 95\% of the bunds realized were not damaged, however, we found a silting up of the drainage channels due to the sandy of it upland. This sand is permanently carried in the lowlands during flow due to erosion [22,23,24,25]. At Banflagouè-Fon, only some secondary bunds were destroyed by the runoff caused by a rain of $83 \mathrm{~mm}$. Barjongo, many damage on bunds have been observed from the early rain more than $50 \mathrm{~mm}$. in fact, the site of Barjongo is fed by two watersheds with higth slop, which testifies to the complexity of the sudanian lowland. And, Tansega, the impacts were smaller despite the fact that $100 \mathrm{~mm}$ of rain, more thant the daily decennial rain, has been record.

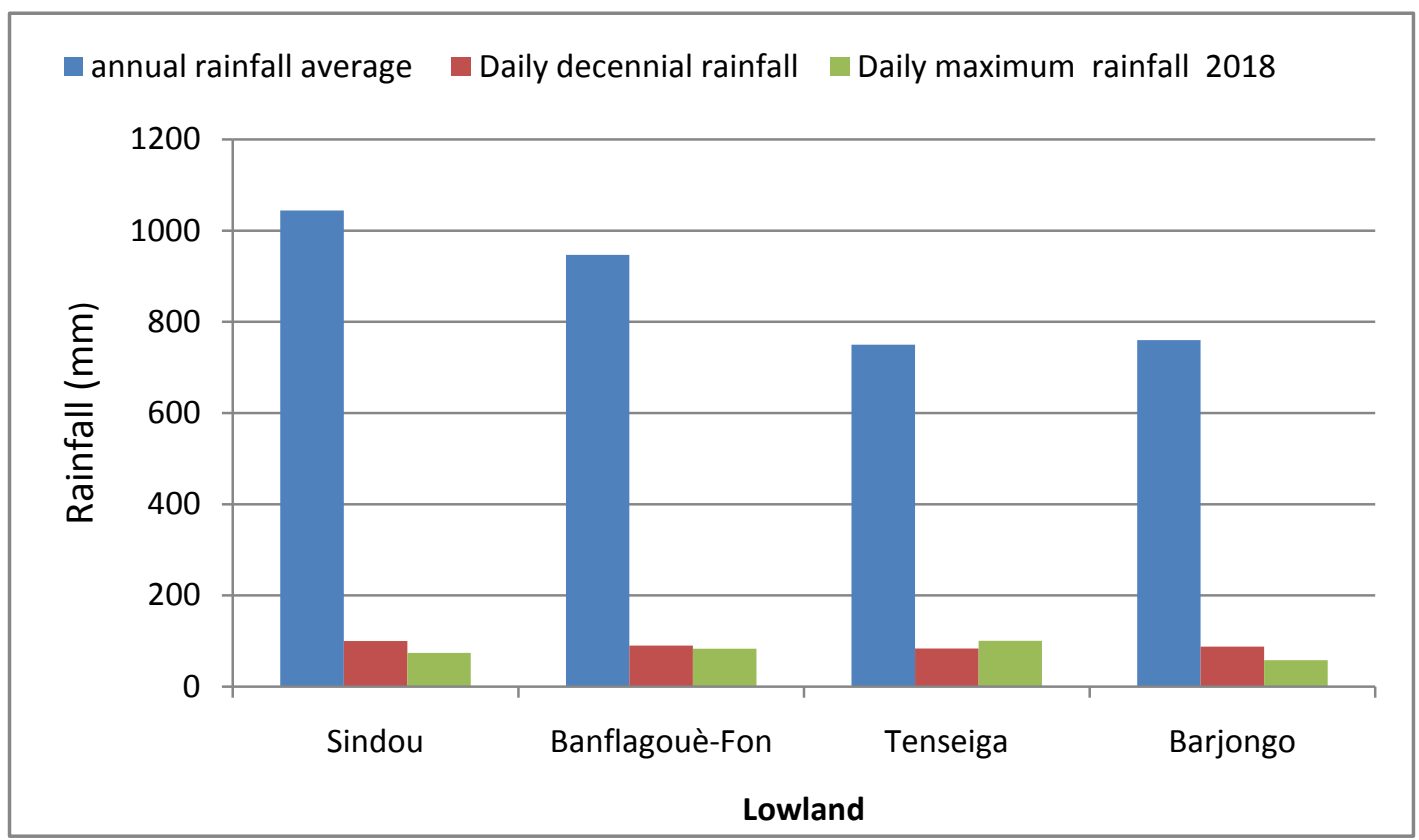

Figure 3. The different characteristic rains
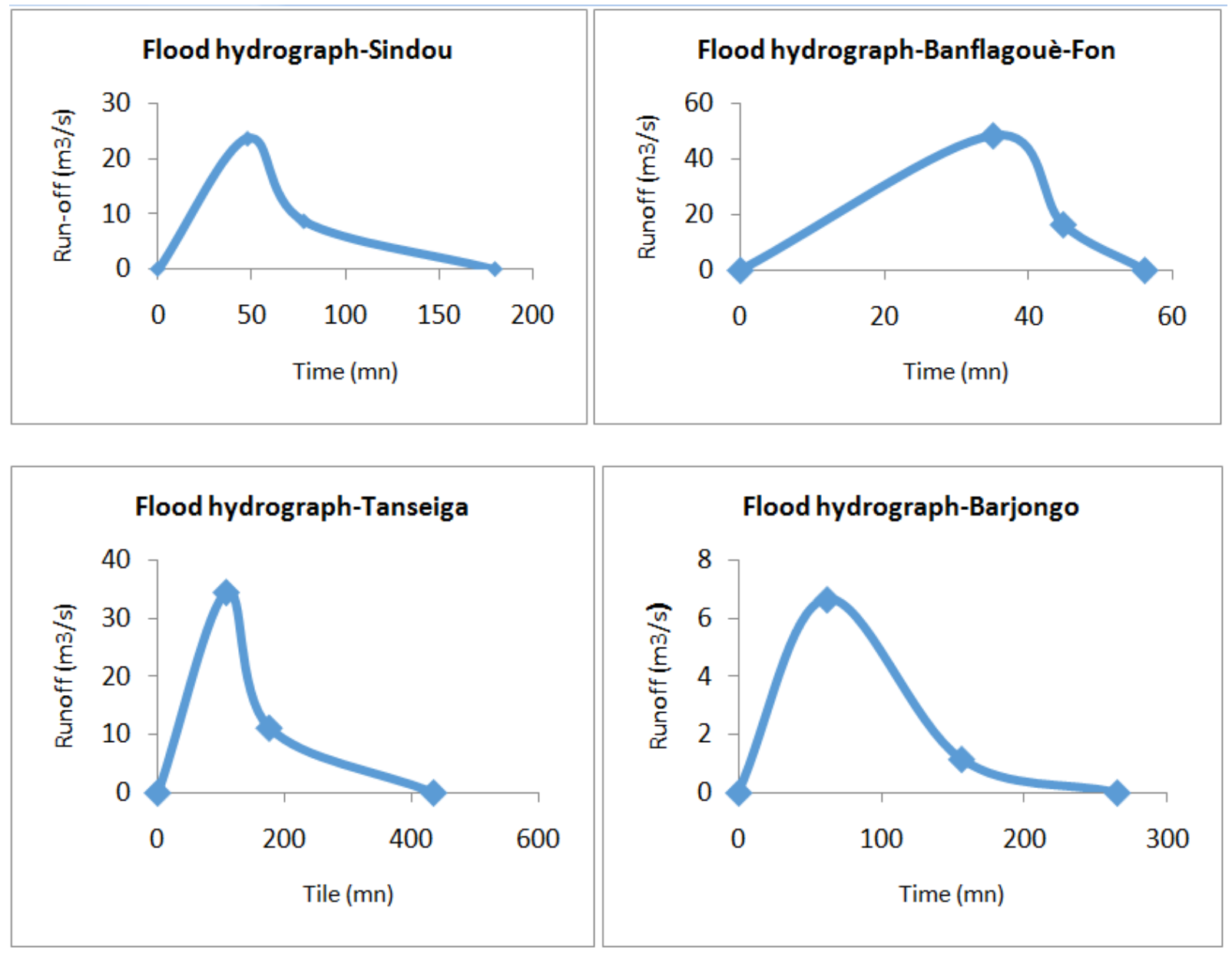

Figure 4. Flood hydrograph in the four lowlands 
Table 1. Section of adapted smart valley bunds

\begin{tabular}{|l|c|c|}
\hline Description & main bund with Rubble stones $\left.\mathbf{( m}^{\mathbf{2}}\right)$ & Secondary bund with only lowland land $\left(\mathbf{m}^{\mathbf{2}}\right)$ \\
\hline lowland in the northern sudanian zone & $0,5-0,8$ & $0,32-0,48$ \\
\hline lowland in the south sudanian zone & $0,32-0.66$ & $0,19-0.36$ \\
\hline
\end{tabular}

\section{Conclusion}

Smart-Valleys adapted bunds in some soudanians' lowlands development have demonstrated their effectiveness at three levels: simplicity of implementation, resistance to flow and its impact in increasing the resilience of small holder farmers to the effects of climate change. Indeed, these bunds, at lower cost and achievable by the small holder farmers helps them to slow down runoff, increases infiltration and retains a standing water that reduces the effects of pockets of drought during crop production. But this smart valley adapted technology is not adapted for all the sudanian lowlands because in this study, this approach was success $75 \%$ in lowlands tested.

\section{Acknowledgements}

This research was funded by the German Development Cooperation (GIZ) through the "Climate-smart rice technologies to enhance resilience of smallholder rice farmers in Burkina-Faso" (CSA-Burkina) project. Our thanks to: all the small holder farmers in Sindou, Banflagouè-Fon, Tanseiga and Barjongo; the technicians of CAP of Matourkou and provincial direction of ministry of agriculture who help us during these tests, and Max Didier Tchobo from AfricaRice.

\section{References}

[1] Albergel J. (1988). Fonctionnement hydrologique des bas-fonds: synthèse préliminaire, Dakar.

[2] Hulme, M.: Climatic perspectives on Sahelian desiccation: 1973-1998, Glob. Environ. Chang., 11, 1929. 2001.

[3] Aggarwal P. K., \& Mall R. K. Climate change and rice yields in diverse agro-environments of India. II. Effect of uncertainties in scenarios and crop models on impact assessment. Climatic Change, 52, 331-343, 2002

[4] Gerald C. NELSON. Changement climatique: Impact sur l'agriculture et coût de l'adaptation. Institut international de recherche sur les alimentaires (IFPRI) Washington, D.C. 7p, 2009.

[5] Li T., Hasegawa T., Yin X. Y., Zhu Y., Boote K., Adam M., Gaydon D.. Uncertainties in predicting rice yield by current crop models under a wide range of climatic conditions. Global Change Biology, 21, 1328-1341. 2015.

[6] Bouman B. A. M., Kropff M. J., Tuong T. P., Wopereis M. C. S., Ten Berge H. F. M. and Van Laar H. H. ORYZA2000: Modeling lowland rice. Los Baños: IRRI, 2001.

[7] Dama Balima M.M.. Aménagements des bas-fonds au Burkina Faso : opportinuité pour l'amélioration des conditions de vie des femmes rurale. U.d. Ouagadougou, Ed. (002), p.19, 2013.

[8] Erenstein O, Sumber J, Oswald A, Levasseur V, Kore H. What future for integrated rice-vegetable production systems in West
African lowlands? Agric Syst 88(2-3): 376-394, 2006.

[9] Fukai S, Sitisaung P, Chanphengsay M. Increasing production of rainfed lowland rice in drought prone environments: A case study in Thailand and Laos. Plant Prod. Sci. 1:75-82. 1998.

[10] Tsubo M, Basnayake, Fukai S, Sihathep V, Siyavong P, Sipaseuth, Chanphengsay $M$. Top sequential effects on water balance and productivity in rainfed lowland rice ecosystem in Southern Laos. Field Crops Res. 97:209-220. 2006.

[11] Gockowski J, Ndoumbe M.. The adoption of intensive mono crop horticulture in southern Cameroon. Agric Econ 30:195-202, 2004.

[12] AfricaRice (2006) « Le système d'information sur les bas-fonds de l'Afrique en l'Ouest 》 WAIVIS. Available at http://www.warda.org/waivis (accessed 2006).

[13] Defoer T. D. J.. Smart-valleys: Mannel du formateur-facilitateur, (Africa Rice) Abidjan, Côte d'Ivoire, 2017.

[14] KOUENIA K, 2017. Evaluation des potentialités de mise en œuvre des smart valleys dans la zone soudanienne du Burkina Faso: cas des régions du Centre-Est, du Plateau Central, des Hauts-Bassins et des Cascades. Mémoire de fin de cycle. Centre Agricole polyvalent de Matourkou, Burkina Faso. 42-43 p.

[15] FAO (s.d.) Apports. Mannuel pour l'estimation des crues decennales et des apports pour les petits bassins versants non jaugés de l'Afrique sahélienne et tropicale. Bulletin FAO d'irrigation et de drainage, (54), 1996.

[16] CIEH (b) Annales des Précipitations Journalières de 1966 a 1980. CIEH- ASECNA-ORSTOM. Benin, 1989, 298 p.; Burkina-Faso 1989, 656 p.; Cameroun, 1990, 747 p.; Centrafrique, 1990, 450 p.; Congo, 1989, 642 p.; Gabon, 1989, 279 p.; Cote d'Ivoire, 1989, 609 p.; Mali, 1989, 782 p.; Mauritanie, 1990, 181 p.; Niger, 1990, 372 p.; Senegal, 1990, 675 p.; Tchad, 1990, 466 p.; Togo, 369 p. 1989.

[17] AfricaRice, 2017: Smart-Valleys: Manuel du formateurfacilitateur, Available at http://www.africarice.org.

[18] Lilley JM, Fukai S. Effect of timing and severity of water deficit on four diverse rice cultivars.I. Rooting pattern and soil water extraction. Field Crops Res. 37:205-213. 1994.

[19] Kilian J, Teissier J, Raunet M, Lidon B, Ahmadi N, Traore B, Legoupil JC. Caractérisation agro écologique des bas fonds: Etude de leur utilisation traditionnelle et des systèmes de production en place Bouaké, Côte d'Ivoire, ADRAO-CBF, Rapp. Tech. Du comité d'Experts du Consortium Bas-fonds P. 50. 1999.

[20] Stefanou SE, Saxena S.. Education, experience, and allocative efficiency: a dual approach. Am. J. Agric. Econ. 70: 338-345. 1988

[21] Frappart, F., Hiernaux, P., Guichard, F., Mougin, E., Kergoat, L., Arjounin, M., Lavenu, F., Koité, M., Paturel, J.-E., and Lebel, T.: Rainfall regime across the Sahel band in the Gourma region, Mali, J. Hydrol., 375, 128-142, 2009.

[22] Aich, V., Liersch, S., Vetter, T., Andersson, J., Müller, E., and Hattermann, F.: Climate or Land Use? Attribution of Changes in River Flooding in the Sahel Zone, Water, 7, 2796-2820, 2015.

[23] Li, K. Y., Coe, M. T., Ramankutty, N., and Jong, R. De: Modeling the hydrological impact of land-use change in West Africa, $J$. Hydrol., 337, 258-268, 2007.

[24] Marzolff, I., Poesen, J. and Ries J.B.. Short to medium-term gully development?: Human activity and gully erosion variability in selected Spanish gully catchments, Landf. Anal., 17, 111-116. 2011.

[25] Tsubo M, Basnayake, Fukai S, Sihathep V, Siyavong P, Sipaseuth, Chanphengsay M. Top sequential effects on water balance and productivity in rainfed lowland rice ecosystem in Southern Laos. Field Crops Res. 97: 209-220. 2006. 